\title{
PENGARUH PENGGUNAAN KOMPOS DAUN PAITAN (Tithonia diversifolia) TERHADAP PERTUMBUHAN DAN PRODUKSI TANAMAN SAWI HIJAU (Brassica juncea L.)
}

\author{
Nur Halimah ${ }^{1 *}$ dan Ferdinant ${ }^{2}$ \\ 1. Mahasiswa Program Studi Budidaya Tanaman Hortikultura, Jurusan Budidaya Tanaman \\ Pangan,Politeknik Pertanian Negeri Payakumbuh \\ 2. Dosen Program Studi Budidaya Tanaman Hortikultura, Jurusan Budidaya Tanaman \\ Pangan,Politeknik Pertanian Negeri Payakumbuh \\ *Email :noerhalimah971@ gmail.com
}

\begin{abstract}
ABSTRAK
Sawi hijau (Brassica juncea L.) merupakan salah satu komoditas tanaman hortikultura dari jenis sayursayuran yang memiliki macam-macam manfaat dan kegunaan dalam kehidupan masyarakat sehari-hari. Peningkatan produksi tanaman sawi hijau masih terbuka lebar untuk memenuhi kebutuhan dan tingkat konsumsi sayuran nasional. Usaha untuk meningkatkan pertumbuhan dan produksi sawi hijau dapat dilakukan dengan menjaga kesuburan lahan pertanian. Kesuburan lahan dapat dijaga dengan melakukan penambahan pupuk organik. Salah satu pupuk organik yang bisa digunakan adalah kompos daun paitan (Tithonia diversifolia). Tujuan dari kajian ini adalah mengetahui pengaruh penggunaan kompos daun paitan terhadap pertumbuhan dan produksi tanaman sawi hijau serta mendapatkan dosis kompos daun paitan yang paling baik terhadap pertumbuhan dan produksi tanaman sawi hijau (Brassica juncea L.). Artikel ini dilaksanakan bertepatan pada kegiatan PKPM dilengkapi dengan studi literatur yang dilaksanakan mulai bulan Maret sampai bulan Juli 2020. Berdasarkan kajian pada beberapa hasil studi literatur dapat disimpulkan penggunaan beberapa dosis kompos daun paitan berpengaruh lebih baik terhadap pertumbuhan dan produksi tanaman sawi hijau dibandingkan kontrol serta penggunaan kompos daun paitan dengan dosis 0,75 kg memberikan hasil terbaik terhadap pertumbuhan dan produksi tanaman sawi hijau dibandingkan perlakuan lain. Berdasarkan kesimpulan dari kajian pada beberapa hasil penelitian disarankan untuk menggunakan kompos daun paitan dengan dosis $0,75 \mathrm{~kg}$ guna meningkatkan pertumbuhan dan produksi tanaman sawi hijau.
\end{abstract}

Kata kunci : Sawi hijau, kompos, tithonia, pertumbuhan dan produksi.

\section{PENDAHULUAN}

Permintaan terhadap komoditas sayuran terus meningkat seiring dengan meningkatnya kebutuhan konsumsi sayuran per kapita per orang serta kebutuhan terhadap produk hortikultura yang lebih berkualitas. Konsumsi sayuran di Indonesia tahun 2018 adalah 248 gram/kapita/hari (BKP, 2019). Hal ini masih rendah dari syarat minimum yang direkomendasikan oleh WHO yakni 400 gram per kapita per hari (Deny, 2020). Oleh karena itu peningkatan produksi tanaman sayuran masih terbuka lebar untuk memenuhi kebutuhan dan tingkat konsumsi sayuran nasional. Salah satu sayuran yang dapat dibudidayakan adalah sawi hijau.

Sawi hijau (Brassica juncea L.) merupakan salah satu komoditas tanaman hortikultura dari jenis sayur-sayuran yang memanfaatkan daun-daun yang masih muda.
Daun sawi sebagai bahan makanan memiliki macam-macam manfaat dan kegunaan dalam kehidupan masyarakat sehari-hari. Sawi hijau selain dimanfaatkan sebagai bahan makanan, juga dapat dimanfaatkan untuk pengobatan. Selain itu sawi hijau juga digemari konsumen karena memiliki kandungan provitamin A dan asam askorbat yang tinggi (Pracaya, 2011).

Daerah asal tanaman sawi hijau diduga dari Tiongkok dan Asia Timur, konon di daerah Tiongkok, tanaman ini telah dibudidayakan sejak 2.500 tahun yang lalu, kemudian menyebar luas ke Filipina dan Taiwan. Masuknya sawi hijau ke wilayah Indonesia diduga pada abad ke XIX. Bersamaan dengan lintas perdagangan jenis sayuran sub-tropis lainnya, terutama kelompok kubis-kubisan. Daerah pusat penyebaran sawi antara lain Cipanas, Lembang, Pangalengan, Malang dan Tosari. Terutama daerah yang mempunyai ketinggian di atas 1.000 mdpl (Susila, 2013). 
Usaha untuk meningkatkan pertumbuhan dan produksi sawi hijau dapat dilakukan dengan menjaga kesuburan lahan pertanian supaya kesinambungan usaha pertanian tetap terlaksana. Kesuburan lahan dapat dijaga dengan melakukan penambahan pupuk organik. Menurut Sunaryo (2011) pupuk organik adalah pupuk yang berasal dari sisa-sisa organisme hidup seperti tumbuhan, hewan, ataupun limbah organik lainnya. Pupuk organik sangat bermanfaat bagi peningkatan pertumbuhan dan produksi pertanian baik kualitas maupun kuantitas, mengurangi pencemaran lingkungan dan meningkatkan kualitas lahan secara berkelanjutan. Penggunaan pupuk organik dalam jangka panjang dapat meningkatkan produktivitas lahan dan dapat mencegah degradasi lahan. Sumber bahan untuk pupuk organik sangat beraneka ragam, dengan karakteristik fisik dan kandungan kimia yang sangat beragam, sehingga pengaruh dari penggunaan pupuk organik terhadap lahan dan tanaman dapat bervariasi.

Salah satu pupuk organik yang bisa digunakan adalah kompos daun paitan (Tithonia diversifolia). Menurut Sutanto (2002), kompos merupakan jenis pupuk yang merupakan hasil akhir penguraian sisa-sisa hewan maupun tumbuhan yang berfungsi sebagai penyuplai unsur hara tanah sehingga dapat digunakan untuk memperbaiki tanah secara fisik, kimiawi, dan biologis.

Menurut Hartatik (2007), Tithonia diversifolia merupakan sejenis gulma yang dapat tumbuh di tanah-tanah terlantar. Tanaman ini telah menyebar hampir di seluruh dunia, dan sudah dimanfaatkan sebagai kompos oleh petani di Kenya, namun di Indonesia belum banyak dimanfaatkan. Tithonia diversifolia mengandung unsur hara yang tinggi terutama N, P, K yaitu 3,50-4,00 \%, 0,35-0,38 $\%$ dan 3,50-4,10 \%, 0,58 \% Ca dan 0,27 \% Mg yang dapat meningkatkan $\mathrm{pH}$ tanah serta menurunkan Al-dd tanah. Hal ini membuat Tithonia diversifolia dapat dimanfaatkan untuk meningkatkan kesuburan tanah sehingga dapat meningkatkan pertumbuhan dan produksi tanaman sawi hijau.

\section{METODE PELAKSANAAN}

Data dan informasi diperoleh dari studi literatur terkait penggunaan kompos paitan terhadap pertumbuhan dan produksi tanaman sawi hijau.

\section{PEMBAHASAN}

Berdasarkan kajian terhadap budidaya tanaman sawi hijau menggunakan perlakuan kontrol, kompos daun paitan dosis $0,25 \mathrm{~kg}$ (A1), kompos daun paitan dosis $0,50 \mathrm{~kg}$ (A2), kompos daun paitan dosis $0,75 \mathrm{~kg}$ (A3), kompos daun paitan dosis $1 \mathrm{~kg}$ (A4), dan kompos daun paitan dosis 1,25 kg (A5) dengan beberapa parameter yang diamati didapatkan bahwa dosis kompos yang memberikan pengaruh lebih baik terhadap pertumbuhan dan produksi tanaman sawi hijau terdapat pada perlakuan kompos daun paitan dengan dosis $0,75 \mathrm{~kg}$ (A3). Jika dibandingkan dengan deskripsi tanaman sawi hijau varietas yang mirip yaitu varietas kumala, hasil rata-rata tinggi tanaman, rata-rata jumlah daun, rata-rata panjang daun, dan rata-rata lebar daun tanaman sawi hijau yang diperoleh pada perlakuan tersebut yakni $33,83 \mathrm{~cm}, 10,25$ helai, $20,43 \mathrm{~cm}$, dan $9,32 \mathrm{~cm}$ telah mencapai deskripsi tinggi tanaman, jumlah daun, panjang daun terluar dan lebar daun terluar tanaman sawi hijau dari varietas tersebut yakni $32-33,3 \mathrm{~cm}, 9-10$ helai, 19,5-20,8 cm, dan 8,87 cm.

Penggunaan kompos paitan terhadap tanaman budidaya sudah banyak dilakukan oleh beberapa peneliti. Salah satunya yaitu tanaman budidaya yang masih satu famili dengan tanaman sawi hijau. Menurut hasil penelitian Sari (2019), penggunaan kompos paitan dengan dosis kompos $2 \mathrm{~kg} /$ plot menghasilkan rata-rata jumlah daun terbanyak serta rata-rata lebar daun terlebar pada tanaman pakcoy. Jarak tanam yang digunakan yaitu $30 \mathrm{~cm}$ x $30 \mathrm{~cm}$ dengan 9 tanaman per plotnya, sehingga satu tanaman bisa mendapatkan dosis kompos sebanyak $0,22 \mathrm{~kg}$. Menurut hasil penelitian Nurzulaikah et al., (2017), penggunaan kompos paitan dengan dosis 30 ton/ha menghasilkan pertumbuhan terbaik pada tanaman kailan. Jarak tanam yang biasa digunakan pada tanaman kailan yaitu $40 \mathrm{~cm}$ x $40 \mathrm{~cm}$ (Rubatzky dan Yamaguchi, 1999), dengan dosis 30 ton/ha bisa diberikan per tanamannya sebanyak 0,48 
kg. Dosis tersebut merupakan dosis tertinggi pada perlakuan yang diberikan. Jika dibandingkan dengan penggunaan kompos daun paitan dengan dosis $0,75 \mathrm{~kg}$ (A3), dosis $0,22 \mathrm{~kg}$ serta $0,48 \mathrm{~kg}$ per tanamannya masih jauh lebih sedikit. Tidak menutup kemungkinan bila kompos diberikan dengan dosis yang lebih tinggi bisa menghasilkan pertumbuhan yang lebih baik pada tanaman pakcoy serta kailan yang mana hal ini perlu diteliti lebih lanjut. Jika diterapkan pada tanaman sawi hijau penggunaan kompos dengan dosis $0,22 \mathrm{~kg}$ dan $0,48 \mathrm{~kg}$ per tanaman diduga belum mampu mengoptimalkan pertumbuhan dan produksi tanaman sawi hijau. Hal ini bisa dilihat dari hasil penggunaan kompos daun paitan dengan dosis yang lebih rendah dari $0,75 \mathrm{~kg}$ (A3) pada tabel 1 yakni perlakuan kompos daun paitan dosis $0,25 \mathrm{~kg}$ (A1) dan kompos daun paitan dosis $0,50 \mathrm{~kg}$ (A2) yang menghasilkan rata-rata jumlah daun, rata-rata lebar daun, rata-rata panjang daun serta berat segar tanaman sawi hijau yang lebih rendah dibandingkan dengan perlakuan kompos daun paitan dosis $0,75 \mathrm{~kg}$ (A3).

Menurut hasil penelitian Simatupang (2014), dosis kompos paitan sebanyak 20 ton/ha $(0,50 \mathrm{~kg}$ per tanaman) yang diberikan pada tanaman kol bunga menghasilkan laju pertumbuhan jumlah daun tertinggi. Perlakuan dengan dosis yang lebih banyak yaitu 25 ton/ha $(0,625 \mathrm{~kg}$ per tanaman) serta 30 ton $/ \mathrm{ha}(0,75 \mathrm{~kg}$ per tanaman) tidak menghasilkan laju pertumbuhan jumlah daun tanaman kol bunga yang lebih tinggi dibandingkan pemberian kompos paitan sebanyak 20 ton/ha. Dosis kompos paitan yang diberikan pada tanaman kol bunga sebesar $0,50 \mathrm{~kg}$ per tanaman diduga sudah mencukupi unsur hara untuk mendukung laju pertumbuhan jumlah daun tanaman kol bunga. Dosis yang lebih rendah yaitu 5 ton/ha $(0,125 \mathrm{~kg}$ per tanaman $), 10$ ton/ha $(0,25 \mathrm{~kg}$ per tanaman), dan 15 ton/ha $(0,375 \mathrm{~kg}$ per tanaman) menghasilkan laju pertumbuhan jumlah daun tanaman kol bunga yang lebih rendah dari dosis $0,50 \mathrm{~kg}$ per tanaman. Jika dibandingkan dengan kompos daun paitan dosis $0,75 \mathrm{~kg}$ (A3), dosis 0,50 kg masih lebih rendah, namun jika dosis ditingkatkan tidak menunjukkan adanya laju pertumbuhan jumlah daun tanaman kol bunga yang lebih baik sehingga meningkatkan dosis akan menjadi tidak efektif. Pada tanaman sawi hijau sendiri penggunaan kompos daun paitan dengan dosis $0,75 \mathrm{~kg}$ (A3) lebih efektif untuk mendukung pertumbuhan dan produksi tanaman sawi hijau dibandingkan dosis $0,50 \mathrm{~kg}$. Hal ini dikarenakan penggunaan kompos daun paitan dosis $0,75 \mathrm{~kg}$ (A3) menghasilkan rata-rata jumlah daun tanaman sawi hijau yang lebih banyak dibandingkan dengaan dosis $0,50 \mathrm{~kg}$. Berdasarkan kajian terhadap hasil pengamatan penelitian-penelitian di atas dapat dilihat perbedaan dosis kompos paitan yang yang tepat untuk tanaman. Hal ini menandakan setiap tanaman memiliki kebutuhan kompos dengan dosis yang berbeda-beda. Pemberian kompos dengan dosis yang berbeda tentunya memberikan efek yang berbeda pada tanaman.

Penggunaan kompos dengan dosis yang tepat mampu memperbaiki kesuburan tanah, yakni memperbaiki sifat fisik, kimia, dan biologi tanah, dimana tanah adalah tempat tumbuh tanaman yang akan berpengaruh terhadap pertumbuhan dan produksi tanaman. Sifat fisik tanah yang baik dapat ditandai dengan struktur tanah yang gembur, pada tanah yang gembur ketersediaan oksigen di dalam tanah akan lebih banyak sehingga aerasi di dalam tanah akan berjalan dengan lancar. Aerasi yang berjalan lancar tersebut tentunya baik untuk akar tanaman karena dapat memperlancar proses fisiologi yang berada di akar. Tanah yang gembur juga memudahkan air masuk ke dalam tanah sehingga erosi dapat dicegah dan proses pencucian unsur hara dapat diminimalisir. Air yang tersedia cukup pada tanah dapat digunakan oleh tanaman untuk kebutuhan proses fisiologinya.

Perbaikan sifat kimia dan biologi tanah berkaitan dengan unsur hara yang tersedia untuk tanaman serta mikroorganisme tanah. Menurut Hutomo et al., (2016), perbaikan sifat kimia dan biologi tanah diduga dapat meningkatkan ketersediaan unsur hara. Penambahan kompos dalam tanah juga dapat meningkatkan nilai KTK tanah (Setyorini et al., 2006). KTK tanah yang tinggi akan menyediakan hara makro dan mikromineral yang lebih lama. Kompos banyak mengandung mikroorganisme, penambahan kompos juga berarti penambahan mikroorganisme ke dalam tanah. Menurut Setyorini et al., (2006), dengan ditambahkannya kompos tidak hanya jutaan mikroorganisme yang ditambahkan, akan tetapi mikroorganisme yang ada dalam tanah juga 
terpacu untuk berkembang. Gas $\mathrm{CO}_{2}$ yang dihasilkan oleh mikroorganisme tanah akan dipergunakan untuk fotosintesis oleh tanaman sehingga pertumbuhan tanaman akan lebih cepat. Selain itu aktivitas mikroorganisme di dalam kompos menghasilkan hormon-hormon pertumbuhan, misalnya auksin, giberelin, dan sitokinin yang memacu pertumbuhan dan perkembangan rambut-rambut akar sehingga pencarian makanan lebih luas.

Kompos mengandung berbagai unsur hara makro dan mikromineral yang dibutuhkan tanaman. Unsur hara yang terdapat dalam kompos merupakan unsur hara yang sudah tersedia dalam bentuk terlarut karena telah mengalami proses dekomposisi oleh mikroorganisme pengurai sehingga dapat digunakan oleh tanaman. Menurut Hartatik (2007), Tithonia diversifolia mengandung unsur hara, yaitu 3,50-4,00 \% N, 0,35-0,38\% $\mathrm{P}, 3,50-4,10 \% \mathrm{~K}, 0,59 \% \mathrm{Ca}$ dan $0,27 \% \mathrm{Mg}$. Ketersediaan unsur hara yang cukup dapat meningkatkan pertumbuhan dan produksi tanaman. Menurut Putra et al., (2019), kecukupan akan unsur hara terhadap tanaman akan menentukan nilai biomassa tanaman, karena besar kecilnya unsur hara yang diberikan dan diserap oleh tanaman sangat mempengaruhi laju pertumbuhan vegetatif dan generatif tanaman.

Unsur $\mathrm{N}$ yang terkandung dalam kompos daun paitan, dibutuhkan dalam pembentukan daun tanaman. Menurut Nyakpa et al. dalam Parasian et al., (2018), proses pembentukan daun tidak terlepas dari unsur hara seperti nitrogen dan fosfor yang tersedia bagi tanaman. Selain itu Menurut Indriyani et al., (2018), unsur hara nitrogen pada tanaman berfungsi untuk meningkatkan pertumbuhan daun sehingga daun akan menjadi lebih banyak jumlahnya dan akan menjadi lebih besar dengan warna yang lebih hijau. Unsur hara kalium yang terdapat pada kompos daun paitan juga bermanfaat bagi pembentukan daun dikarenakan unsur kalium berperan dalam memperkuat tubuh tanaman sehingga daun tidak mudah gugur.

Proses pembentukan daun selain menentukan jumlah daun juga berkaitan terhadap lebar serta panjang daun. Lebar daun serta panjang daun tanaman akan menentukan luas daun tanaman yang terbentuk, dimana semakin panjang daun tanaman dan semakin lebar daun tanaman berpengaruh terhadap pertambahan ukuran luas daun yang dimiliki oleh tanaman. Perlakuan kompos daun paitan dosis $0,75 \mathrm{~kg}$ (A3) memiliki hasil rata-rata daun terpanjang serta rata-rata daun terlebar sehingga hal ini dapat berpengaruh terhadap besarnya ukuran luas daun tanaman sawi hijau pada perlakuan tersebut. Daun merupakan alat yang digunakan dalam proses fotosintesis. Tanaman sawi hijau yang mempunyai luas daun yang lebih besar akan lebih efisien dalam penyerapan sinar matahari yang bermanfaat dalam proses fotosintesis sehingga dapat memperlancar prosesnya. Proses fotosintesis yang berjalan lancar akan meningkatkan fotosintat yang selanjutnya akan ditranslokasikan ke bagian-bagian vegetatif tanaman sehingga jumlah daun, panjang daun, lebar daun akan meningkat yang diiringi dengan besarnya hasil berat basah tanaman sawi hijau. Menurut Gardner dalam Kresnanita (2013), produk fotosintesis akan segera digunakan untuk cadangan makanan, pembentukkan senyawa struktural, respirasi dan pembentukan sel-sel aktif. Seberapa besar efisiensi tanaman membagikan hasil fotosintesis ke organ mempunyai pengaruh besar terhadap hasil panen.

Hasil pengamatan pertumbuhan dan produksi tanaman sawi hijau pada perlakuan kontrol, kompos daun paitan dosis $0,25 \mathrm{~kg}$ (A1), kompos daun paitan dosis $0,5 \mathrm{~kg}$ (A2), kompos daun paitan dosis $1 \mathrm{~kg}$ (A4), kompos daun paitan dosis $1,25 \mathrm{~kg}$ (A5) didapatkan hasil rata-rata jumlah daun, rata-rata panjang daun, rata-rata lebar daun, serta rata-rata berat basah tanaman sawi hijau lebih rendah dari perlakuan kompos daun paitan dosis 0,75 kg (A3). Perlakuan-perlakuan tersebut diperkirakan belum memenuhi dosis yang sesuai untuk memperbaiki kesuburan fisik, kimia, dan biologi tanah. Pada perlakuan kontrol, A1, dan A2 unsur hara yang tersedia bagi tanaman sawi hijau kurang mencukupi untuk mendukung pertumbuhan dan produksinya, apalagi pada perlakuan kontrol yang sama sekali tidak dilakukan pemberian bahan organik berupa kompos daun paitan ke dalamnya. Menurut Taufiq et al., (2007), pemberian pupuk organik dapat menyumbangkan unsur hara bagi tanaman. Secara umum bila tanaman kekurangan unsur hara maka proses metabolisme tanaman akan terganggu dan 
proses pertumbuhan tanaman menjadi terhambat.

Pada perlakuan A4 dan A5 meskipun dosis kompos daun paitan yang diberikan lebih banyak dibandingkan dengan perlakuan A3, tidak menunjukkan adanya peningkatan pertumbuhan serta produksi tanaman sawi hijau yang lebih tinggi dari perlakuan A3. Berdasarkan hal tersebut pemberian kompos daun paitan dengan dosis $0,75 \mathrm{~kg}$ (A3) sudah paling optimal untuk mendukung pertumbuhan dan produksi tanaman sawi hijau. Kompos sebaiknya diberikan dengan dosis yang optimal agar sesuai dengan kebutuhan tanaman. Kebutuhan tanaman tersebut salah satunya yaitu kebutuhan akan unsur hara. Menurut Sutedjo dalam Pasaribu (2019), komposisi dan kadar unsur hara makro dan mikro sangat berpengaruh terhadap pertumbuhan tanaman, sehingga pemberian pupuk harus seimbang dan sesuai dengan kebutuhan tanaman. Selain itu menurut Neliyati dalam Sepwanti et al., (2016), pemberian kompos dengan dosis yang terlalu tinggi atau berlebihan akan mengakibatkan ketidakseimbangan penyerapan unsur hara pada proses metabolisme tanaman karena jaringan tanaman membutuhkan konsenterasi unsur hara tertentu, jika terdapat melebihi kebutuhan tanaman maka akan menurunkan atau menekan pertumbuhan tanaman.

Salah satu pengaruh pemberian kompos pada tanah adalah kompos dapat menambah kemampuan tanah menahan air sehingga dapat melembabkan tanah. Menurut Pasaribu (2019), pemberian kompos berlebih dapat menyebabkan penimbunan unsur hara pada media tanam yang dapat dilihat dari kandungan air yang lebih banyak pada media tanam. Terlalu banyaknya air dalam tanah dapat mempengaruhi pertumbuhan akar, sehingga bisa membuat akar membusuk. Akibatnya penyerapan unsur hara menjadi terganggu. Hal ini tentunya dapat mempengaruhi pertumbuhan dan produksi tanaman karena unsur hara sangat diperlukan tanaman untuk pertumbuhan dan produksinya.

\section{KESIMPULAN}

Berdasarkan kajian pada beberapa hasil penelitian yang telah dipaparkan dan telah dilakukan pembahasan maka dapat diambil kesimpulan sebagai berkut :
1. Penggunaan beberapa dosis kompos daun paitan (Tithonia diversifolia) berpengaruh lebih baik terhadap pertumbuhan dan produksi tanaman sawi hijau dibandingkan kontrol.

2. Penggunaan kompos daun paitan (Tithonia diversifolia) dengan dosis $0,75 \mathrm{~kg}$ memberikan hasil terbaik terhadap pertumbuhan dan produksi tanaman sawi hijau dibandingkan perlakuan lain.

\section{DAFTAR PUSTAKA}

Buletin Konsumsi Pangan. 2019. Sekretariat Jenderal Kementerian Pertanian.

Cahyono, B. 2003. Teknik dan Strategi Budidaya Sawi Hijau (Pat-Tsai). Yogyakarta. Yayasan Pustaka Nusatama.

Deny S. "Konsumsi Sayuran dan Buah Masyarakat RI Masih di Bawah Standar FAO”. Http//www.liputan6.com.

Djaja W. 2008. Langkah Jitu Membuat Kompos dari Kotoran Ternak dan Sampah. Jakarta. PT Agromedia Pustaka.

Fransisca, S. 2009. Respon Pertumbuhan dan Produksi Sawi (Brassica juncea L.) Terhadap Penggunaan Pupuk Kascing dan Pupuk Organik Cair. Skripsi. Medan. Universitas Sumatera Utara.

Hardjowigeno, S. 2003. Klasifikasi Tanah dan Pedogenesis. Jakarta : Akademika Pressindo.

Harizena, IN. D. 2012. Pengaruh Jenis dan Dosis Mol TerhadapKualitas Kompos Sampah Rumah Tangga. Skripsi. Program Studi Ilmu Tanah, Jurusan Agroekoteknologi, Fakultas Pertanian, Universitas Udayana.

Hartatik, W. 2007. "Tithonia diversifolia Sebagai Pupuk Hijau". Warta Penelitian dan Pengembangan Pertanian. 
Haryanto, E, T. Suhartini dan E. Rahayu. 2002. Sawi dan Selada. Jakarta. Penebar Swadaya.

Haryanto, Eko. 2007. Sawi dan Selada. Jakarta : Penebar Swadaya.

Hutomo, P., Sampoerna, F. Puspita. 2016. "Pemberian Campuran Trichokompos Dengan Abu Janjang Kelapa Sawit Di Medium Subsoil Ultisol Terhadap Pertumbuhan Kelapa Sawit (Elaeis guineensisJacq.) Di Pembibitan Utama". JOM Faperta.

Indriyani, N., T. Wardiyati, M. Nawawi. 2018. "Pengaruh Macam Pupuk Kandang Terhadap Pertumbuhan dan Hasil Tanaman Brassica rapa L. dan Brassica juncea L". Jurnal Produksi Tanaman.

Istarofah dan Z. Salamah. 2017. "Pertumbuhan Tanaman Sawi Hijau (Brassica juncea L.) Dengan Pemberian Kompos Berbahan Dasar Daun Paitan (Tithonia diversifolia)". Bio-site.

Kurniansyah, D. 2010. Produksi Kedelai Organik Panen Kering dari Dua Varietas Kedelai dengan Berbagai Jenis Pupuk Organik. Skripsi. Departemen Agronomi dan Hortikultura. Fakultas Pertanian. Bogor. Institut Pertanian Bogor.

Lingga, P dan Marsono. 2004. Petunjuk Penggunaan Pupuk. Jakarta. Penebar Swadaya.

Margiyanto, E. 2007. Hortikultura. Bantul : Cahaya Tani.

Murbandono, Leonardus. 2008. Membuat Kompos. Jakarta. Penebar Swadaya.

Nurhidayah, L. 2018. Perbedaan Pertumbuhan Tanaman Sawi Hijau (Brassica juncea L.) Pada Media Tanam Hidroponik dan Media Tanah.

Nurzulaikah, N. Soverda, T. Novita, 2017. "Pengaruh Kompos Paitan (Tithonia diversifolia) Terhadap Pertumbuhan dan Hasil Kailan (Brassica oleracea)". Fakultas Pertanian. Universitas Jambi.

Oktavia, F. 2015. "Peran Produk Olahan Serabut Kelapa Sebagai Penunjang Kelestarian Ekologi”. Balai Penelitian Tanaman Palma. Prosiding Konferensi Nasional Kelapa VIII.

Pasaribu M. Y. A. 2019. "Pengaruh Pemberian Pupuk Kompos Plus Terhadap Pertumbuhan Tanaman Sawi Pakcoy (Brassica rapa L.)". Skripsi. Universitas Sanata Dharma Yogyakarta. Yogyakarta.

Pracaya, 2011. Bertanam Sayur Organik. Jakarta : Penebar Swadaya.

Putra, J. L., S. M. Sholihah, Suryani. 2019. "Respon Pertumbuhan dan Hasil Beberapa Jenis Tanaman Sayuran Terhadap Pupuk Kotoran Jangkrik Dengan Sistem Vertikultur". Jurnal Ilmiah Respati.

Rukmana, R. 2005. Bertanam Sawi dan Petsai. Jakarta : Penebar Swadaya.

Sari W. P. 2019. "Efektifitas Aplikasi Pupuk Paitan (Tithonia diversifolia) dan Fungi Mikoriza Arbuskular Terhadap Pertumbuhan dan Produksi Pakcoy (Brassica rapa L.)". Skripsi. Universitas Medan Area.

Sastrahidajat, I.H dan Soemono, 1996. Budidaya Tanaman Tropika. Surabaya. Usaha Nasional.

Seni, I. A. Y., I Wayan, D. A., dan Ni Wayan, S. S. 2013. "Analisis Kualitas Larutan Mol (Mikroorganisme Lokal) Berbasis Daun Gamal (Gliricidia sepium)". Denpasar : Universitas Udayana. E-Jurnal Agroekoteknologi Tropika.

Sentana S. 2010. Pupuk Organik, Peluang dan Kendalanya. Dalam Seminar Nasional Teknik Kimia "Kejuangan". Pengembangan Teknologi Kimia untuk Pengolahan Sumber Daya Alam Indonesia di Yogyakarta. 
Sepwanti, C., M. Rahmawati, E. Kesumawati. 2016. "Pengaruh Varietas dan Dosis Kompos yang Diperkaya Trichoderma harzanium Terhadap Pertumbuhan dan Hasil Tanaman Cabai Merah (Capsicum annuum L.)". Jurnal Kawista I.

Setyorini, D. R. Saraswati, E. K. Anwar. 2006."Kompos".

Departemen

Pertanian.

Http//www.Balittanah.go.id. Diakses tanggal 18 Juni 2020.

Simamora, Suhut., dan Salundik. 2006. Meningkatkan Kualitas Kompos. Jakarta. Agro Media Pustaka.

Simatupang, 2014. "Pengaruh Dosis Kompos Paitan (Tithonia diversifolia) Terhadap Pertumbuhan dan Hasil Kol Bunga pada Sistem Pertanian Organik". Skripsi. Univeristas Bengkulu.

Suhardi, 1990. Dasar-Dasar Bercocok Tanam. Yogyakarta. Kanisius.

Sunaryo, Y.2011. Pembuatan dan Uji Aplikasi Pupuk Organik Cair Berbahan Baku Kotoran Hewan pada Hidroponik Sawi. Prosiding Seminar Nasional. Menjadi Andal dan Berbudi Pekerti. Universitas Sarjanawiyata Tamansiswa Yogyakarta bekerja sama dengan Kepel Press.

Supartha, I, Y, N. G. Wijana, G, M. Adnyana. 2012. Aplikasi Jenis Pupuk Organik pada Tanaman Padi System Pertanian Organik. J. Agrotektropika.

Suriawiria, U. 2003. Mikrobiologi Air dan Dasar-dasar Pengolahan Buangan Secara Biologis. Bandung. PT. Alami.

Susila, A. D., 2013. Sistem Hidroponik. Modul Matakuliah Dasar Dasar Hortikultura Fakultas Pertanian .Bogor. Institut Pertanian Bogor.

Sutanto, Racman. 2002. Pertanian Organik : Menuju Pertanian Alternatif dan Berkelanjutan. Jakarta : Kanisius.
Taufiq A., Kuntyastuti, H. Prahoro dan Wardani, Y. 2007. "Pemberian Kapur dan Pupuk Kandang Pada Kedelai di Lahan Kering Masam". Jurnal Penelitian Tanaman Pangan.

Widarti, B. N., Wardhini, W.K Sarwono, E. 2015. "Pengaruh Rasio C/N Bahan Baku pada Pembuatan Kompos dari Kubis dan Kulit Pisang”. Jurnal Integrasi Proses.

Wijaya, Kelik. 2010. Pengaruh Konsenterasi dan Frekuensi Pemberian Pupuk Organik Cair Hasil Perombakan Anaerob Limbah Makanan Terhadap Pertumbuhan Tanaman Sawi (Brassica juncea L.). Skripsi. Surakarta : Universitas Sebelas Maret. 